В.Р. Шагінян, І.В. Фільчаков, В.І. Матяш, А.О. Руденко, П.А. Дьяченко, Ю.В. Парфенюк, В.Ю. Клюс, О.Л. Панасюк, Л.В. Березіна

\title{
ДОСВІД ВИЗНАЧЕННЯ ІНТРАТЕКАЛЬНОГО СИНТЕЗУ АНТИТІЛ У ПАЦІЕНТІВ З УРАЖЕННЯМИ ЦЕНТРАЛЬНОЇ НЕРВОВОЇ СИСТЕМИ
}

\author{
ДУ «Інститут епідеміології та інфекційних хвороб ім. Л.В. Громашевського НАМН України»
}

\begin{abstract}
Мета роботи. Вивчити частоту інтратекального синтезу специфрічних антитіл у пацієнтів зі запальними ураженнями центральної нервової системи.

Пацієнти і методи. В роботі наведені дані визначення інтратекального синтезу специярічних антитіл (ITCA) у 90 пацієнтів, які проходили лікування в клініці ДУ «Інститут епідеміології та інсрекційних хвороб ім. Л.В. Громашевського». Дослідження включало кількісне визначення антитіл класу Ig $\mathrm{G}$ в сироватці крові (CK) та спинномозковій рідині (CMP) до нейротропних збудників: вірусу простого герпесу 1/2 типу, цитомегаловірусу, вірусу Епштейна-Барр, вірусу оперізувального лишаю, вірусу кору, вірусу краснухи, бореліям. Розрахунки показників ITCA проведені за методикою Reiber Н. Стан гематоенцефралічного бар'єру (ГЕБ) оцінювали за допомогою коефріцієнту альбуміну (Qalb) з урахуванням вікових норм.
\end{abstract}

Результати. ITСА встановлений у $(25,6 \pm 4,6) \%$ обстежених пацієнтів з ураженнями ЦНС. У пацієнтів з ITCA найчастіше (у 52,2 \%) одночасно були присутні антитіла до декількох нейротропних збудників. Виявлення ITCA в обстежених пацієнтів не залежало від концентрації специорічних антитіл у СК і СМР і не супроводжувалося порушенням фоункції ГЕБ. Випадки диссрункції ГЕБ у пацієнтів з ITCА та без ІTСА виявлялися з однаковою частотою (13,0 та 13,6 \% відповідно).

Висновок. Наявність специфрічних антитіл до декількох нейротропних вірусів у СМР була виявлена майже у всіх обстежених пацієнтів. Навіть кількісне визначення у СМР антитіл до збудників нейроінфрекцій не дозволяє встановити етіологічний чинник хвороби. 3 іншого боку, розрахунок показників ITCA дає можливість лабораторно підтвердити клінічні діагнози інфрекційних або автоімунних уражень ЦНС.

Ключові слова: нейроінфрекції, інтратекальний синтез специярічних антитіл.
Діагностика інсрекційних та автоімунних уражень центральної нервової системи (ЦНС) представляє значні труднощі. Інструментальні методи досліджень, які широко використовуються в неврологічній практиці, не дозволяють встановити причину захворювання. Значно розширює можливості етіологічної діагностики лабораторне дослідження спинномозкової рідини (СМР). Між тим, важливим залишається питання, які саме методи лабораторної діагностики дають можливість встановити чинник, що лежить в основі патологічного процесу в ЦНС.

Відомо, що специфрічні антитіла, які циркулюють у крові, можуть бути виявлені й у СМР, але у менших концентраціях. Тому визначення антитіл у СМР, як правило, віддзеркалює імунну відповідь в цілому, не дозволяючи встановити наявність інсрекційного процесу саме у ЦНС, отже має незначну діагностичну цінність. Деякі лікарі практикують дослідження СМР на наявність «ранніх антитіл», тобто імуноглобулінів класів М або А ( $\operatorname{lgM}, \lg A)$. Між тим, за сучасними уявленнями, виявлення специфрічних IgM в CMP не може бути розцінено так само, як виявлення цих антитіл у крові, тобто не є маркером гострого інсрекційного процесу в ЦНС. Скоріш за все, не представляє діагностичної цінності і виявлення в CMP IgA, які в 90 \% випадків проникають через гематоенцефралічний бар'єр (ГЕБ) [1]. На теперішній час для встановлення етіології інсекційних уражень ЦНС лікарі найчастіше використовують метод ПЛР, який дозволяє визначати фррагменти генетичного матеріалу (ДНК/РНК) збудників. Але і цей метод має обмеження. Так, при хронічних ураженнях ЦНС може бути отриманий хибнонегативний результат у ПЛР-дослідженні за рахунок того, що більшість нейротропних вірусів знаходяться у тканинах мозку і їх фррагменти можуть бути присутні у СMP у незначній кількості та короткий проміжок часу при загостренні хвороби. В той же час відомо, що наявність вогнища запалення у тканинах мозку супроводжується 
ОРИГІНАЛЬНІ ДОСЛІДЖЕННЯ

активацією гуморальної імунної відповіді в межах ЦНС. Це явище отримало назву інтратекальна імунна відповідь, яка реалізується за участі ектопічної лімсроїдної тканини, так званих третинних лімфроїдних утворень (ТЛУ). Натепер зібрано багато доказів, які вказують на ключову роль ТлУ в орормуванні та підтримці інтратекального синтезу антитіл (ITCA). Слід зазначити, що ТлУ в окремих випадках можуть досягати значного розміру (діаметром до 1,1 мм), що дозволяє їх візуалізувати, однак у більшості випадків їх структура складається приблизно з 50-100 клітин, що ускладнює їх виявлення [2-4].

Вважають, що ITCA класу G (IgG) визначається в половині випадків, обумовлених запальним процесом у ЦНС. Визначити саме інтратекальну продукцію специфрічних антитіл, відокремлюючи її від антитіл, які проникають через ГЕБ, можна за допомогою спеціальних прийомів, які враховують ступінь дисфункції ГЕБ. Проведені наукові дослідження свідчать про можливість використання методу визначення інтратекального синтезу IgG, у тому числі і специфрічних, для діагностики та встановлення етіології уражень ЦНС [5-7].

Одним 3 основоположників досліджень в ділянці інтратекальної імунної відповіді можна вважати німецького вченого H. Reiber, який розробив математичну модель розрахунку показників інтратекального синтезу імуноглобулінів з урахуванням проникності ГЕБ [8]. Спочатку передбачалося, що ITCA $€$ ознакою специфрічної імунної відповіді, але подальші дослідження показали, що ITCA визначається не тільки в разі гострого інфекційного процесу в ЦНС, коли збудник знаходиться в паренхімі мозку і есректори імунної відповіді мігрують у тканини мозку, викликаючи пошкодження (енцефраліт, мієліт, менінгоенцефаліт). Можлива й антигеннезалежна активація В-клітин пам'яті за участі Т-лімфоцитів і Toll-рецепторів на В-лімфроцитах. У результаті розвивається поліспециорічна імунна відповідь з наявністю ITCA різної специфрічності одночасно. Іншими словами, ITCA не обов язково $€$ індикатором гострого інфекційного процесу, а може бути відображенням хронічного запального процесу автоімунної природи або результатом перенесеної інсрекції в минулому. У таблиці 1 представлена порівняльна характеристика показників СМР, які, за даними H. Reiber, дозволяють диференціювати імунну відповідь при гострому процесі та поліспецифічну імунну відповідь, яка обумовлена антигеннезалежною активацією В-клітин [9].

Дослідження, спрямовані на вивчення патологічних процесів у ЦНС, які обумовлюють ITСА, тривають. За даними, отриманими у ряді європейських країн, визначення ITCA в поєднанні з результатами загальноклінічних досліджень СМР, у тому числі оцінки ступеня про-
Таблиця 1

Порівняльна характеристика деяких показників СМР при різних варіантах імунної відповіді (за даними Н. Reiber, 2016)

\begin{tabular}{|c|c|c|}
\hline Показник & $\begin{array}{c}\text { Специфічна } \\
\text { імунна } \\
\text { відповідь }\end{array}$ & $\begin{array}{l}\text { Поліспецисрічна } \\
\text { імунна відповідь }\end{array}$ \\
\hline Авідність антитіл & Низька & Висока \\
\hline Фракція загальних IgG & $10-20 \%$ & $0,1-0,5 \%$ \\
\hline Кількість клітин & Велика & Низька (<20) \\
\hline $\begin{array}{l}\text { Співвідношення } \\
\text { концентрації альбуміну } \\
\text { в СМР і сироватці крові } \\
\left(\mathrm{Q}_{\text {Alb }}\right)\end{array}$ & Високе & $\begin{array}{c}\text { Низьке } \\
\left(<15 \times 10^{-3}\right)\end{array}$ \\
\hline $\begin{array}{l}\text { Концентрація антитіл у } \\
\text { динаміці захворювання }\end{array}$ & Знижується & Стабільна \\
\hline $\begin{array}{l}\text { Фрагменти ДНК, РНК, } \\
\text { антигени збудників }\end{array}$ & $+/-$ & Не виявляються \\
\hline
\end{tabular}

никності гематоенцефралічного та гематолікворного бар'єрів (ГЕБ/ГЛБ), може бути перспективним методом діагностики гострих і хронічних уражень ЦНС інсрекційної і автоімунної природи.

Мета роботи - вивчити частоту інтратекального синтезу специфічних антитіл у пацієнтів з ураженнями центральної нервової системи.

\section{Пацієнти і методи}

Визначення інтратекального синтезу специфрічних антитіл проведено у 90 пацієнтів, які поступили в Центр інфекційних уражень нервової системи ДУ «Інститут епідеміології та інфекційних хвороб ім. Л.В. Громашевського». Методика включала кількісне визначення антитіл класу IgG (в од/мл) у сироватці крові (СК) та СМР до наступних нейротропних збудників: цитомегаловірусу (Ab CMV), вірусів простого герпесу 1/2 типу (Ab HSV 1/2), Епштейна-Барр (Ab $\mathrm{EBV}$ ), оперізувального лишаю (Ab VZV), кору (Ab Msls), краснухи (Ab Rub), борелій (Ab Bor.). Забір крові та спинномозкової рідини проводився 3 інтервалом не більше однієї години. Дослідження біоматеріалу проводили методом ІФА з використанням тест-систем Euroimmun (Німеччина) на сертифікованому обладнанні LabLine (Китай). Розрахунок ITCA проводили за методикою H. Reiber за допомогою програми на базі Excel, наданої виробником тест-систем. У СК та СМР також визначали кількість альбуміну методом імунотурбідиметрії на сертифрікованому автоматичному біохімічному аналізаторі ChemRay 240 (Китай). Стан ГЕБ/ГЛБ оцінювали за допомогою коефріцієнту альбуміну $\left(\mathrm{Q}_{\mathrm{alb}}\right)$, рівного відношенню концентрації аль- 


\section{ОРИГІНАЛЬНІ ДОСЛІДЖЕННЯ}

буміну в СМР (мг/л) до концентрації альбуміну в СК (г/л) 3 урахуванням вікових норм [10]. Ступінь диссрункції ГЕБ визначали на підставі критеріїв Schliep-Felgenhauer [11]. Статистичну обробку даних здійснювали за допомогою комп'ютерної програми Excel.

\section{Результати досліджень та їх обговорення}

Проведене дослідження дозволило встановити, що частота виявлення специфрічних антитіл класу IgG до нейротропних збудників у СК обстежених пацієнтів була досить високою та коливалася від 100 \% (до вірусу Епштейна-Барр) до 25,6 \% (до борелій). При наявності антитіл в СК, вони також виявлялися в СМР, що обумовлено їх дисрузіє і проникністю ГЕБ/ГЛБ (мал. 1). Слід зазначити, що частота виявлення специсічних антитіл в СК та СMP у обстежених пацієнтів практично не відрізнялась. Достовірна розбіжність між частотою виявлення антитіл в СК та СМР була доведена лише до вірусу кору (у $(88,9 \pm 3,3) \%$ пацієнтів антитіла знайдені в СК і у $(73,3 \pm 4,7)$ \% в СMP, p<0,05). Показники виявлення антитіл до герпесвірусів (HSV, CMV, EBV, VZV) у CK та CMP у групі обстежених пацієнтів практично не відрізнялись. Цей фракт може бути пояснений більш низькою концентрацією анамнестичних антитіл (після перенесеного захворювання або вакцинації проти кору та краснухи) на відміну від імунної відповіді до герпесвірусів, які персистують в організмі людини. Порівняно невисока частота виявлення антитіл до борелій, мабуть, пов'язана з відносно невеликою частотою інорікування в обстеженій групі пацієнтів.

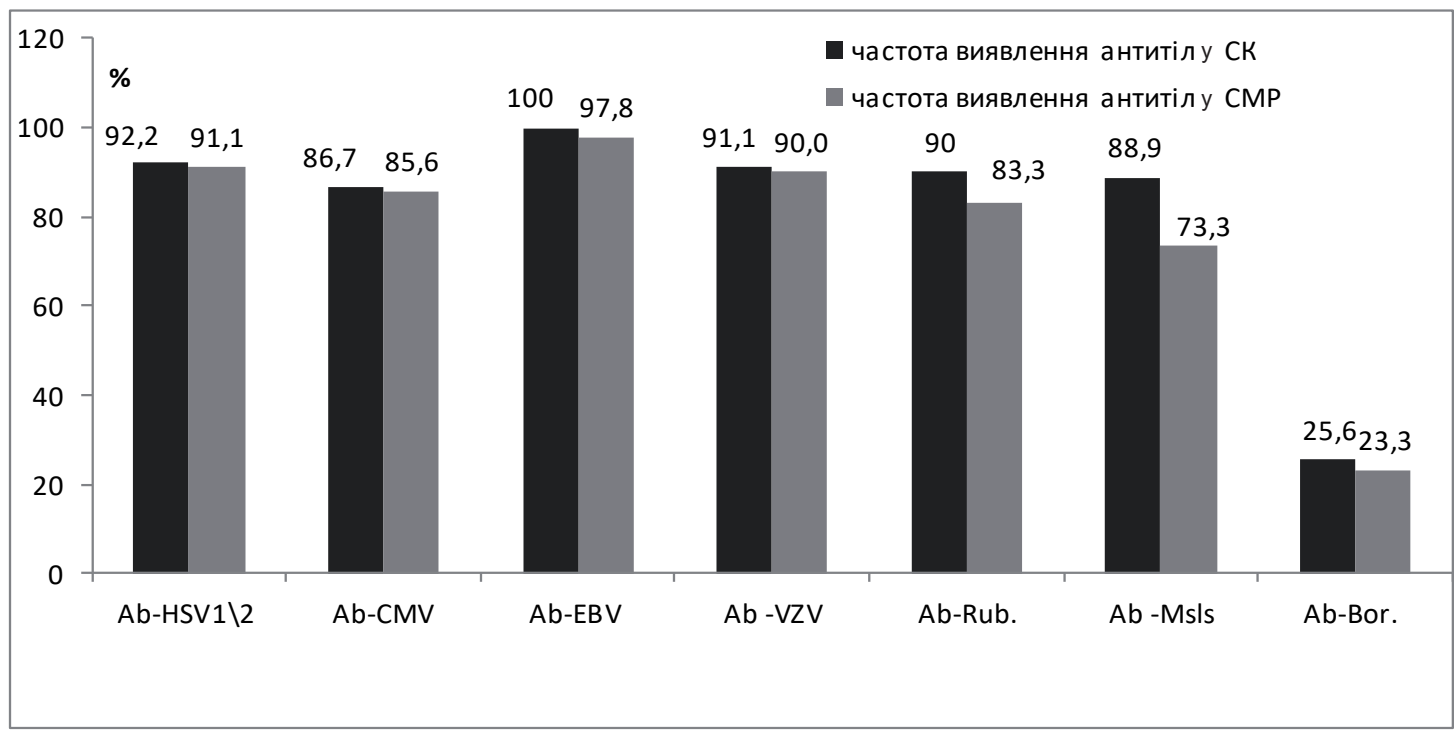

Мал. 1. Частота виявлення специфічних антитіл IgG у СK та CMP обстежених пацієнтів.

Таким чином, практично у всіх обстежених пацієнтів встановлена наявність антитіл класу IgG до декількох збудників герпесвірусних індрекцій (які вважають етіологічним чинником переважної більшості інфекційних уражень ЦНС) як у СК, так і у СMP. 3 мал. 1 видно, що антитіла до HSV були присутні у CMP в 91,1 \%, до CMV - у 86,7 \%, до EBV - у 100 \% обстежених пацієнтів. Отже, встановити етіологію ураження ЦНС на підставі наявності специфрічних антитіл IgG навіть у CMP не уявляється можливим. Слід також зазначити, що результати ПлР-дослідження СМР на наявність генетичного матеріалу вірусів герпес-групи майже у 90 \% обстежених пацієнтів були негативними.

Серед 90 обстежених пацієнтів у $23(25,6 \pm 4,6) \%$ було визначено ITCA до нейротропних збудників. При цьому у 47,8 \% випадків виявлявся ITCA до одного збудника, у 4,4 \% - до двох, у 47,8 \% - до трьох і більше. В останньому випадку інтратекальна продукція антитіл оцінювалась нами як поліспецифрічна імунна відповідь, що потребувала подальшої диференційної діагностики. Так, в одного пацієнта, з порушеним ГЕБ/ГЛБ (внаслідок травми і шунтування шлуночків мозку) можна було припустити антигеннезалежну активацію В-лімфроцитів у вогнищі запалення 3 подальшою продукцією антитіл різної специсічності. В іншому випадку, у пацієнта 3 попереднім діагнозом розсіяний енцесраломієліт, нами також був встановлений ITСА до всіх досліджених збудників, що підтвердило автоімунну природу ураження ЦНС.

Наявність ITCA ми порівняли з частотою виявлення антитіл у СМР (мал. 2). Антитіла до вірусів простого герпесу та Епштейна-Барр у СMP були присутні у всіх 
пацієнтів з ITCA, але частота інтратекального синтезу антитіл до зазначених збудників була відносно невисокою - 30,4 та 34,8 \% відповідно. В той же час, при невисокій частоті виявлення Ab-Bor. у CMP (17,4\%), у 75 \% пацієнтів за наявності у СМР антитіл до борелій визначався їх інтратекальний синтез. 3 них у двох випадках специсрічність антитіл підтверджена методом імунного блоту. В одному випадку одночасно визначався ITCA до борелій, вірусу Епштейна-Барр і вірусу простого герпесу. У даного пацієнта наявність Ab-Bor. не була підтверджена імунним блотом, що дало підставу припустити перехресну реакцію з іншими антигенами, а сам ITCA розглядати як результат антигеннезалежної активації В-лімфоцитів автоімунної природи.

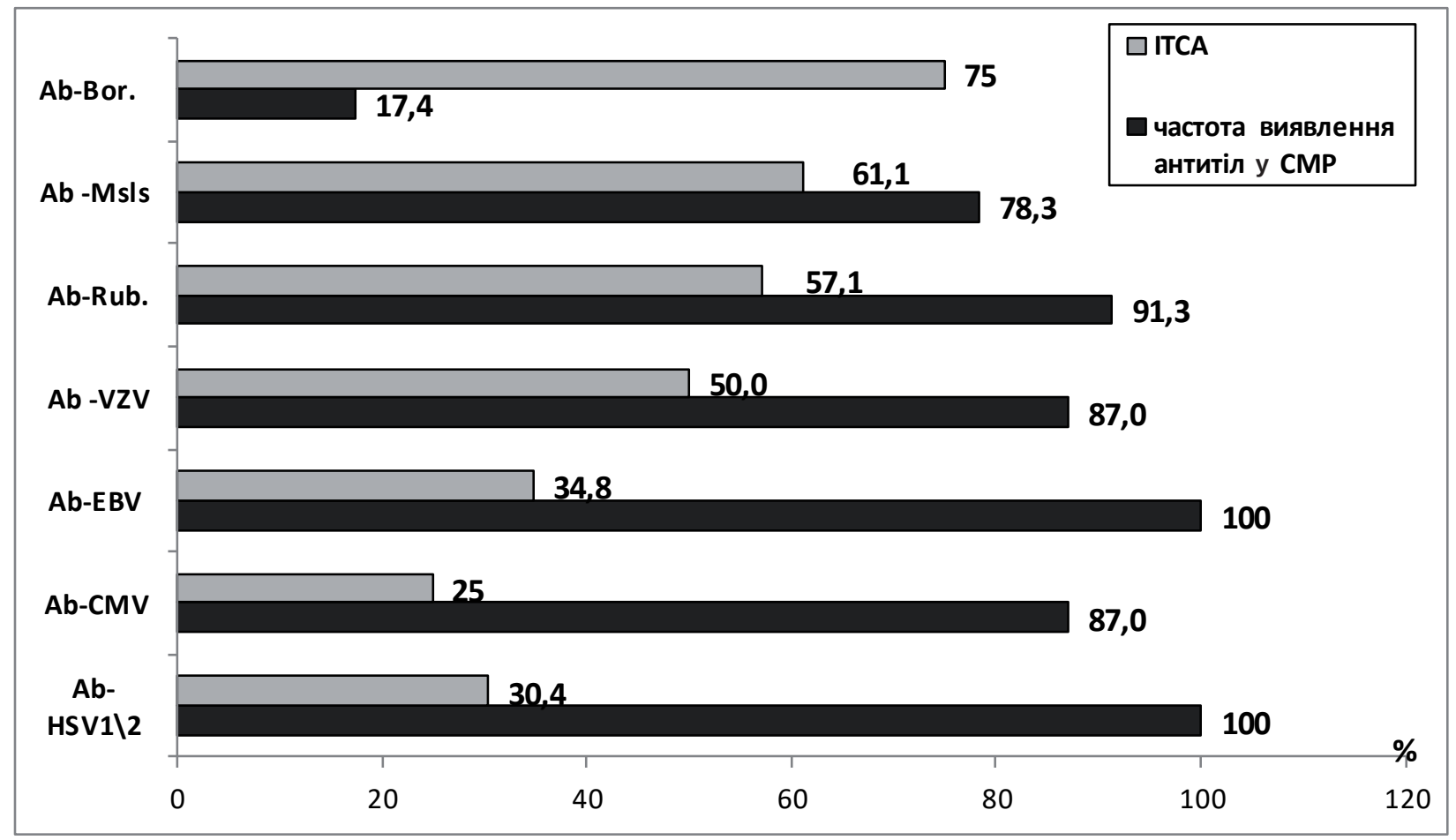

Мал. 2. Частота виявлення специфічних антитіл у CMP і частка їх інтратекального синтезу.

Як свідчать дані, наведені на мал. 2, при виявленні в СМР антитіл до вірусу кору, в 61,1 \% випадків виявлявся ITCA до цього вірусу. Всього ж Ab-Msls в CMP були виявлені у 78,3 \% пацієнтів. У той же час, антитіла до CMV в CMP були присутні у $87 \%$ обстежених, а ITCA до цього вірусу виявлявся лише у $25 \%$ пацієнтів. Наведені дані наглядно демонструють, що виявлення специфрічних антитіл в СМР не може розглядатися як етіологічний чинник ураження ЦНС.

За наявності специфрічних антитіл у СМР, далеко не у всіх пацієнтів був встановлений ITCA, кореляції між частотою виявлення специфічних антитіл у СМР та виявленням ITCA до цього збудника не встановлено. Слід також зауважити, що кількісні показники виявлення специфрічних антитіл класу IgG до нейротропних збудників (в од./мл) в СК та СМР обстежених пацієнтів не корелювали 3 їх інтратекальною продукцією чи їі відсутністю.
Таким чином, слід визнати більшу діагностичну цінність методу визначення ITCА порівняно з виявленням антитіл у СМР.

У нашому дослідженні були клінічні випадки, коли виявлення ITCA свідчило про активацію інорекційного процесу. Цікавим $€$ клінічне спостереження, коли виявлення ITCA стало підтвердженням активації інфекційного процесу вірусного ґенезу. Пацієнт, попередньо обстежений в Центрі розсіяного склерозу, був спрямований на додаткове обстеження до Центру інфекційних уражень нервової системи нашого Інституту. Виявлений у нього ITCA до VZV (тільки до одного збудника) супроводжувався наявністю фрагментів вірусної ДНК в СМР, що в сукупності з результатами клінічного дослідження дозволило підтвердити активацію VZV-інфекції у даного пацієнта. У двох випадках виявлення ITCA до борелій дозволило підтвердити клінічний діагноз «нейроборелі03». 
Але, як було зазначено вище, більш ніж у половини пацієнтів був встановлений ITCA до двох або трьох збудників, також були випадки, коли був визначений ITCA тільки до вірусу кору. Це спонукало нас до думки про автоімунну причину запального процесу в ЦНС у цих випадках. Рядом досліджень, проведених іншими авторами, було показано, що ITCA різної специфічності, зокрема до вірусу кору, краснухи, VZV (більш відомий як «MRZ-реакція», скорочення від англійської назви збудників M-measles, R-rubella, Z-zoster) характерний для ряду автоімунних уражень ЦНС, зокрема для розсіяного склерозу (РC) [12-15]. При РС причиною ITCA $€$ формування ектопічної лімфоїдної тканини в паренхімі мозку та її подальша активація імунопатологічними механізмами. У такому випадку стимуляція диференціювання В-лімфоцитів пам'яті в плазмобласти відбувається за відсутності антигенів, за рахунок так званої неспецифічної активації. При цьому, імунна відповідь може відображати індивідуальну історію попередніх інфекцій та імунізацій і залежить від регіональної поширеності тих чи інших інсрекцій [2]. Наші дослідження дозволили встановити «MRZ-реакцію» як лабораторне підтвердження автоімунного ураження ЦНС у двох пацієнтів. В одному випадку був виявлений ITCА до вірусів кору і VZV, в іншому - до вірусів кору і краснухи. Надалі в одного пацієнта в СМР були виявлені олігоклональні антитіла (що є «золотим стандартом» лабораторної діагностики PC). В іншому випадку виявлена «MRZреакція» дозволила підтвердити клінічний діагноз РC.

Окремого обговорення заслуговує роль вірусу Епштейна-Барр у патології ЦНС. У літературі $є$ відомості про те, що Ab-EBV часто виявляються в СК та CMP пацієнтів з РС [16]. На думку авторів, вірус ЕпштейнаБарр виступає в якості тригерного сигналу, потрапляючи в ЦНС і персистуючи в клітинах глії задовго до виникнення інтратекального запалення і фрормування ТЛУ [2]. Інші автори вважають, що активація наївних В-клітин, що проникають в ЦНС, спричинена переважно первинною гострою EBV-інфекцією [16]. Оскільки в момент гострої інфекції продукція специорічних антитіл ще не запущена, ця гіпотеза може пояснити високу (практично 100 \%) частоту виявлення Ab-EBV у хворих з PC і низь- ку частоту ITCA Ab-EBV. Отримані нами дані також свідчать про 100 \% частоту виявлення антитіл в СМР до EBV в обстежених пацієнтів, при цьому частота ITCA була відносно невисокою - 34,8 \% (мал. 2). Не виключено, що це випадки, коли EBV був пусковим механізмом при хронічному нейровірусному ураженні ЦНС, який розвивався на фоні імунопатологічного процесу.

Слід зазначити, що суттєвих порушень функцій ГЕБ/ ГлБ в обстежених пацієнтів не виявлено. Незначні порушення, за критеріями Schliepand-Felgenhauer, були встановлені лише у 13,6 \% пацієнтів без ITCA та 13,0 \% з інтратекальним синтезом антитіл. Тобто, відносно високі концентрації специфрічних антитіл у СМР у пацієнтів з ITCА не були пов'язані з підвищеною проникністю ГЕБ/ ГЛБ, а обумовлені їх безпосередньою продукцією у тканинах мозку.

Проведене дослідження окреслило можливі напрямки використання методу ІТСА для етіологічної і диференційної діагностики інфрекційних, запальних, демієлінізуючих і судинних захворювань ЦНС.

\section{Висновки}

1. Інтратекальний синтез специорічних антитіл встановлено у 23 з 90 (25,6 \%) обстежених пацієнтів з ураженнями ЦНС. У пацієнтів з ІТСА найчастіше (у 52,2 \%) одночасно були присутні антитіла до декількох нейротропних збудників.

2. Виявлення ITCA в обстежених пацієнтів не залежало від концентрації специфічних антитіл у СК і СМР і не супроводжувалося порушенням фрункції ГЕБ/ГЛБ. Випадки дисфункції ГЕБ/ГЛБ у пацієнтів з ITCА та без ITCA виявлялися 3 однаковою частотою (13,0 і 13,6 \% відповідно).

3. У пацієнтів за відсутності ITCA наявність специфрічних антитіл у СМР залежала від їх концентрації в СК і проникності ГЕБ/ГЛБ.

4. Наявність специфрічних антитіл до декількох нейротропних вірусів у СMP встановлена майже у всіх пацієнтів з ураженнями ЦНС, що практично унеможливлює уточнення етіологічного чинника хвороби. Метод визначення ІТСА розширює можливості етіологічної та диференційної діагностики уражень ЦНС.

2. Bonnan M. Does disease-irrelevant intrathecal synthesis in multiple sclerosis make sense in the light of tertiary lymphoid organs? / M. Bonnan // Frontiersin Neurology Multiple Sclerosis and Neuroimmunology. - 2014. - Vol. 5 (Article 27). - P. 1-11. 
3. Bonnan M. Intrathecal IgG synthesis: a resistant and valuable target for future multiple sclerosis treatments / M. Bonnan // Multiple Sclerosis International Volume. - 2015. http://dx.doi. org/10.1155/2015/296184

4. Kuerten S. Tertiary lymphoid organ development coincides with determinant spreading of the myelin-specific $\mathrm{T}$ cell response / S. Kuerten, A. Schickel, C. Kerkloh // Acta Neuropathol. - 2012. Vol. 124, N 6. - P. 861-873.

5. Jacobi C. Quantitation of intrathecal antibodies in cerebrospinal fluid of subacute scleros in gpan encephalitis, herpes simplex encephalitis and multiple sclerosis: discrimination between microorganism-driven and Polyspecific immune response / C. Jacobi, P. Lange, H. Reiber // J. Neuroimmunol. - 2007. - Vol. 187, N 1-2. P. 139-146.

6. Denesa E. Intrathecal synthesis of specific antibodies as a marker of herpes simplex encephalitis in patients with negative PCR / E. Denesa, C. Labachb, H. Duroxaet // Swiss. Med. Wkly. - 2010. Vol. 140. w13107//www.smw.ch

7. Otto $\mathrm{C}$. The fraction of varicella zoster virus-specific antibodies among all intrathecally-produced antibodies discriminates between patients with varicella zoster virus reactivation and multiple sclerosis / C. Otto, J. Hofmann, C. Finke // Fluids Barriers CNS. - 2014. - Vol. 11, N 1. - P. 3

8. Reiber H. Quantification of virus-specific antibodies in cerebrospinal fluid and serum: sensitive and specific detection of antibody synthesis in brain / H. Reiber, P. Lange // Clin. Chem. - 1991. - Vol. 37, N 7. - P. 1153-1160.

9. Reiber H. Knowledge-base for interpretation of cerebrospinal fluid data patterns. Essentials in neurology and psychiatry / $\mathrm{H}$. Reiber // Arq. Neuropsiquiatr. - 2016. - Vol. 74, N 6. - P. 501-512.

\section{References}

1. Reiber, H. (2016). Cerebrospinal fluid data compilation and knowledge-based interpretation of bacterial, viral, parasitic, oncological, chronic inflammatory and demyelinating diseases: diagnostic patterns not to be missed in Neurology and Psychiatry. Arq. Neuropsiquiatr., 74 (5), 336-349.

2. Bonnan, M. (2014). Does disease-irrelevant intrathecal synthesis in multiple sclerosis make sense in the light of tertiary lymphoid organs? Frontiersin Neurology Multiple Sclerosis and Neuroimmunology, 5, 27, 1-11.

3. Bonnan, M. (2015). Intrathecal IgG synthesis: a resistant and valuable target for future multiple sclerosis treatments. Multiple Sclerosis International Volume. http://dx.doi.org/10.1155/2015/296184

4. Kuerten, S., Schickel, A., \& Kerkloh, C. (2012). Tertiary lymphoid organ development coincides with determinant spreading of the myelinspecific T cell response. Acta Neuropathol., 124 (6), 861-873.

5. Jacobi, C., Lange, P., \& Reiber, H. (2007). Quantitation of intrathecal antibodies in cerebrospinal fluid of subacutescleros in gpan encephalitis, herpes simplex encephalitis and multiple sclerosis: discrimination between microorganism-driven and Polyspecific immune response. J. Neuroimmunol., 187 (1-2), 139-146.

6. Denesa, E., Labachb, C., \& Duroxaet, H. (2010). Intrathecal synthesis of specific antibodies as a marker of herpes simplex encephalitis in patients with negative PCR. Swiss Med Wkly, 140:w13107 //www.smw.ch
10. Reiber H. Cerebrospinal fluid analysis: disease-related data patterns and evaluation programs / H. Reiber, J. Peter // J. Neurol. Sci. - 2001. - Vol. 184, N 2. - P. 101-122.

11. Schliep G. Serum-CSF proteingradients, the blood-CSF barrier and local immune response / G. Schliep, K. Felgenhauer // J. Neurol. - 1978. - Vol. 218, N 2. - P. 77-96.

12. Felgenhauer $\mathrm{K}$. The diagnostic significance of antibody specifity indices in multiple sclerosis and herpes virus induced diseases of the nervous system / K. Felgenhauer, H. Reiber // The Clinical Investigator - 1992. - Vol. 70. - P. 28-37.

13. Hottenrott T. The intrathecal, polyspecific antiviral immune response in neurosarcoidosis, acute disseminated encephalomyelitis and autoimmune encephalitis compared to multiple sclerosis in a tertiary hospital cohort / T. Hottenrott, B. Berger // Dersch Fluids Barriers CNS. - 2015. - Vol. 12. - P. 27. DOI 10.1186/s12987-015-0024-8

14. Rosche B. Measles IgG Antibody Index Correlates with T2 Lesion Load on MRI in Patients with Early Multiple Sclerosis / B. Rosche, S. Laurent, S. Conradi // PLoS ONE. - 2012. - Vol. 7, Iss. 1 www.plosone.org.

15. Oligoclonal restriction of antiviral immunoreaction in oligoclonal band-negative MS patients / O. Stich, J. Kluge, J. Speck, S. Rayer // Acta Neurol. Scand. - 2015. - Vol. 131, N 6. - P. 381-388.

16. Otto $C$. Antibody producing $B$ lineage cells invade the central nervous system predominantly at the time of and triggered by acute Epstein-Barr virus infection: A hypothesis on the origin of intrathecal immunoglobulin synthesis in multiple sclerosis / C. Otto, J. Hofmann, K. Ruprecht // Med Hypotheses. - 2016. - Vol. 91. - P. 109-113.
7. Otto, C., Hofmann, J., \& Finke, C. (2014). The fraction of varicella zoster virus-specific antibodies among all intrathecally-produced antibodies discriminates between patients with varicella zoster virus reactivation and multiple sclerosis. Fluids Barriers CNS, 11 (1), 3.

8. Reiber, H., \& Lange, P. (1991). Quantification of virus-specific antibodies in cerebrospinal fluid and serum: sensitive and specific detection of antibody synthesis in brain. Clin. Chem., 37 (7), 1153-1160.

9. Reiber, H. (2016). Knowledge-base for interpretation of cerebrospinal fluid data patterns. Essentials in neurology and psychiatry. Arq. Neuropsiquiatr., 74 (6), 501-512.

10. Reiber, H., \& Peter, J. (2001). Cerebrospinal fluid analysis: disease-related data patterns and evaluation programs. J. Neurol Sci., 184 (2), 101-122.

11. Schliep, G., \& Felgenhauer, K. (1978). Serum-CSF proteingradients, the blood-CSF barrier and local immune response. J. Neurol., 218 (2), 77-96.

12. Felgenhauer, K., \& Reiber, H. (1992). The diagnostic significance of antibody specifity indices in multiple sclerosis and herpes virus induced diseases of the nervous system. The Clinical Investigator, 70, 28-37.

13. Hottenrott, T., \& Berger, B. (2015). The intrathecal, polyspecific antiviral immune response in neurosarcoidosis, acute disseminated encephalomyelitis and autoimmune encephalitis compared to multiple sclerosis in a tertiary hospital cohort. Dersch. Fluids Barriers CNS, $12,27$. 
14. Rosche, B., Laurent, S., \& Conradi, S. (2012). Measles IgG antibody index correlates with T2 lesion load on MRI in patients with early multiple sclerosis. PLOS ONE, 7, www.plosone.org.

15. Stich, O., Kluge, J., Speck, J., \& Rauer, S. (2015). Oligoclonal restriction of antiviral immunoreaction in oligoclonal band-negative MS patients. Acta Neurol. Scand., 131 (6), 381-388.

\section{EXPERIENCE OF DETERMINATION OF INTRATHECAL SYNTHESIS OF ANTIBODIES IN PATIENTS WITH DISEASES OF THE CENTRAL NERVOUS SYSTEM}

V.R. Shahinian, I.V. Filchakov, V.I. Matiash, A.O. Rudenko, P.A. Diachenko, Yu.V. Parfeniuk, V.Yu. Klius, O.L. Panasiuk, L.V. Berezina

L. Hromashevskyi Institute of Epidemiology and Infectious Diseases of the NAMS of Ukraine

SUMMARY. The aim of the work - to study the frequency of intrathecal synthesis of specific antibodies at patients with inflammatory lesions of the central nervous system.

Patients and methods. In this work the data of the determination of intrathecal synthesis of specific antibodies (ITSA) in 90 patients are given who were treated at the Lev Hromashevskyi Institute of Epidemiology and Infectious Diseases. The research included quantitative definition of antibodies of the class IgG in serum (S) and cerebrospinal fluid (CSF) to neurotropic pathogens: herpes simplex virus 1/2, cytomegalovirus, Epstein-Barr virus, varicella zoster virus, rubella virus, Borrelies. Calculations of ITSA indicators were carried out according to the method of Reiber $\mathrm{H}$. The condition of a hematoencephalic barrier (HEB) was estimated by means of coefficient of albumine (Qalb) taking into account age norms.

Results. ITSA was established in $(25.6 \pm 4.6) \%$ of the examined patients with damages of the central nervous system. In patients with ITSA most often (in $52.2 \%$ ) simultaneously present antibodies to several neurotropic pathogens. Detection of ITSA at the examined patients didn't depend on concentration of specific antibodies in $S$ and CSF and wasn't followed by malfunction of HEB. The incidence of HEB dysfunction at patients with ITSA and without ITSA appeared with an identical frequency (13,0\% and 13,6\% respectively).

Conclusion. The presence of specific antibodies to several neurotropic viruses in the CSF was established
16. Otto C., Hofmann J., \& Ruprecht K. (2016). Antibody producing $B$ lineage cells invade the central nervous system predominantly at the time of and triggered by acute Epstein-Barr virus infection: A hypothesis on the origin of intrathecal immunoglobulin synthesis in multiple sclerosis. Med. Hypotheses, 91, 109-113.

at almost all examined patients. Thus, even quantitative definition in CSF of antibodies to neurotropic pathogens doesn't allow establishing the etiologic factor of the disease. On the other hand, calculation of indicators of ITSA gives the chance for laboratory to confirm the clinical diagnoses of infectious or autoimmune lesions of CNS.

Key words: neuroinfections; intrathecal synthesis of specific antibodies.

\section{Відомості про авторів:}

Шагінян В.Р. - д. мед. н., ст. н. с., зав. відділом діагностики інфекційних та паразитарних хвороб ДУ «Інститут епідеміології та інфекційних хвороб ім. Л.В. Громашевського НАМН України»; vrs1808@gmail.com

Фільчаков І.В. - к. мед. н., ст. н. с., провідний н. с. відділу діагностики інсрекційних та паразитарних хвороб дУ «Інститут епідеміології та інфекційних хвороб ім. Л.В. Громашевського НАМН України»; filchakovigor@gmail.com

Матяш В.І. - д. мед. н., проф., зав. відділом інтенсивної терапії та детоксикації ДУ «Інститут епідеміології та інфекційних хвороб ім. Л.В. Громашевського НАМН України»; vim10@ukr.net

Руденко А.О. - д. мед. н., проф., зав. відділом нейроінсрекцій ДУ «Інститут епідеміології та інфрекційних хвороб ім. Л.В. Громашевського НАМН України»; neuro10@bk.ru

Дьяченко П.А. - к. мед. н., ст. н. с. відділу нейроінфекцій ДУ «Інститут епідеміології та інфекційних хвороб ім. Л.В. Громашевського НАМН України»; neuro10@bk.ru

Парфенюк Ю.В. - н. с. відділу діагностики інфекційних та паразитарних хвороб ДУ «Інститут епідеміології та інфекційних хвороб ім. Л.В. Громашевського НАМН України»; prioritet $73 @$ gmail.com

Клюс В.Ю. - молодший н. с. відділу нейроінфекцій дУ «Інститут епідеміології та інфекційних хвороб ім. Л.В. Громашевського НАМН України»; neuro10@bk.ru

Панасюк О.Л. - к. мед. н., ст. н. с. відділу інтенсивної терапії та детоксикації ДУ «Інститут епідеміології та інфекційних хвороб ім. Л.В. Громашевського НАМН України»; newhelen@mail.ru 


\section{ОРИГІНАЛЬНІ ДОСЛІДЖЕННЯ}

Березіна Л.В. - к. мед. н., ст. н. с. відділу інтенсивної терапії та детоксикації ДУ «Інститут епідеміології та інсрекційних хвороб ім. Л.В. Громашевського НАМН України»; berezka1970@ukr.net

\section{Information about authors:}

Shahinian V. - DMS, Senior researcher, Head of the Department of Diagnostics of Infectious and Parasitic Diseases of the State Enterprise «L.V. Hromashevsky Epidemiology and Infectious Diseases Institute of NAMS of Ukraine»; vrs1808@ gmail.com

Filchakov I. - PhD, Senior researcher, Leading researcher of the Department of Diagnostics of Infectious and Parasitic diseases of the State Enterprise «L.V. Hromashevsky Epidemiology and Infectious Diseases Institute of NAMS of Ukraine»; filchakovigor@gmail.com

Matiash V. - DMS, Professor, Head of the Department of Intensive Therapy and Detoxication of the State Enterprise «L.V. Hromashevsky Epidemiology and Infectious Diseases Institute of NAMS of Ukraine»; vim10@ukr.net

Rudenko A. - DMS, Professor, Head of the Department of Neuroinfections of the State Enterprise «L.V. Hromashevsky Epidemiology and Infectious Diseases Institute of NAMS of Ukraine»; neuro10@bk.ru
Diachenko P. - PhD, Senior researcher of the Department of Neuroinfections of the State Enterprise «L.V. Hromashevsky Epidemiology and Infectious Diseases Institute of NAMS of Ukraine»; neuro10@bk.ru

Parfeniuk Yu. - Researcher of the Department of Diagnostics of Infectious and Parasitic Diseases of the State Enterprise «L.V. Hromashevsky Epidemiology and Infectious Diseases Institute of NAMS of Ukraine»; prioritet73@gmail. com

Klius V. - Junior researcher of the Department of Neuroinfections of the State Enterprise «L.V. Hromashevsky Epidemiology and Infectious Diseases Institute of NAMS of Ukraine»; neuro10@bk.ru

Panasiuk O. - PhD, Senior researcher of the Department of Intensive Therapy and Detoxication of the State Enterprise «L.V. Hromashevsky Epidemiology and Infectious Diseases Institute of NAMS of Ukraine»; newhelen@mail.ru

Berezina L. - PhD, Senior researcher of the Department of Intensive Therapy and Detoxication of the State Enterprise «L.V. Hromashevsky Epidemiology and Infectious Diseases Institute of NAMS of Ukraine»; berezka1970@ukr.net

Консрлікт інтересів: немає.

Authors have no conflict of interest to declare.

Отримано 29.06.2017 p 